\title{
A Retrospective Study on Consequences of Cesarean Section in Bovine
}

\author{
S.S. Dhindsa*, G.S. Dhaliwal, Harpreet Singh and S.P.S. Ghuman \\ Department of Veterinary Gynaecology and Obstetrics, Guru Angad Dev Veterinary and \\ Animal Sciences University, Ludhiana, Punjab, India- 141001 \\ *Corresponding author
}

\section{A B S T R A C T}

\section{Keywords}

Bovine, Cesarean section, Dystocia, Retrospective study

Article Info

Accepted:

07 December 2018

Available Online:

10 January 2019
The present study was conducted to analyze the consequences of cesarean section (csection) in terms of survivability and future fertility in bovine. The data from 304 veterinarians working at Civil Veterinary Hospitals, Punjab who performed $128 \mathrm{c}$-sections (Cattle: 70, buffalo: 58) was collected through a specially designed questionnaire and analyzed. A high overall survival rate was observed where indication of c-section was pelvic fracture/abnormal pelvis $(67.7 \%)$ followed by incomplete cervical dilatation (66.7 $\%)$ and fetal monsters $(63.6 \%)$. The overall survival rate in cesarean operated animals was 65.6 per cent. About 18 per cent cesarean operated animals with $<12 \mathrm{~h}$ duration of dystocia conceived, however, none of the animals conceived when dystocia was prolonged for $>12 \mathrm{~h}$. In conclusion, survival and future fertility rates in cesarean operated buffaloes can be improved if time elapsed since occurrence of dystocia is less and a decision to operate the animal is taken earlier.

\section{Introduction}

Bovine c-section is one of the oldest surgical interventions in the field of veterinary science and is a widely used emergency operative technique for surgical delivery of calves in dystocia affected bovine. For the veterinary obstetrician, the development of the c-section has great advantages like fetotomy on a living calf can be avoided as well as other obstetrical problems can be easily solved by the operation. It is generally indicated when obstetrical techniques have either failed or are not applicable to deliver the fetus (Purohit $e t$ al., 2012). The c-section dilemma has been based on poor dam survival rates and poor fertility, however many reports depicted that dam survival is high when the operation is performed early without previous handling (Prabhakar et al., 2002).

In delayed cases, peritonitis may develop following c-section due to leakage of uterine fluids, rupture of suture material and knot failure (Singh et al., 2002). Consequences of peritonitis are uterine adhesions that invariably lead to death or infertility (Dhindsa et al., 2010). Post-operative intra-abdominal adhesion formation is a potential problem following c-section in bovine causing huge 
economic loss to dairy farmers. Actually bovine have an increased tendency to form fibrous adhesions than other species as the former have very low levels of plasminogen activators and high levels of fibrinolytic inhibitors, which favor the adhesion formation. Therefore, bearing in mind csection as an important but complicated surgery in bovine, a retrospective study was conducted to analyze the consequences of bovine c-section performed at the field level to suggest prognostic indicators.

\section{Materials and Methods}

The present study was conducted by analyzing the cesarean operations performed at the field level by contacting 304 veterinarians of the Punjab state. A total of $128 \mathrm{c}$-sections (Cattle: 70, buffalo: 58) performed by field veterinarians, were analyzed. The information regarding type, cause and duration of dystocia, survivability, conception rate, any other postcesarean complication etc. was collected through a specially designed questionnaire as below in Table 1. The technique followed for c-section was paramedian and ventrolateral in right lateral recumbency under local infiltration of anaesthesia. Statistical analysis was done by using $t$ test.

\section{Results and Discussion}

A retrospective study was conducted by contacting 304 veterinarians of the Punjab state. It was observed that most of the veterinarians avoid performing c-sections because of low survivability and fertility following the surgery.

Out of the 304 veterinarians contacted, only 16 veterinarians had performed c-sections at the field level. One veterinarian reported 52 operations, five reported between 7-16 operations and none of the other veterinarian reported more than 3 operations. All the veterinarians performed c-section in paramedian or oblique ventrolateral approach in right lateral recumbent position under local infiltration of anaesthesia using $60-80 \mathrm{ml}$ of Lignocaine hydrochloride 2 per cent solution.

The detail of indications for c-section and the survivability following cesarean in dystocia affected animals is given in Table 2 . In cattle and buffalo, maximum survivability after csection was seen in animals where indication of operation was incomplete cervical dilatation (76.0 and $64.7 \%$, respectively) followed by pelvic fracture/abnormal pelvis (70.0 and $63.6 \%$, respectively) and fetal monsters (66.6 and $62.5 \%$, respectively). This could be due to lesser degree of previous handling or less damage to uterine wall in these indications of c-section (Singh, 1996). Moreover, pelvic fracture/abnormal pelvis are easily diagnosed and hence there are fewer chances of injudicious handling and c-section could be done without any delay. The overall survival rate in cesarean operated cattle and buffalo observed in the present study was higher $(65.6 \%)$ than that observed at the teaching veterinary hospital, Guru Angad Dev Veterinary and Animal Sciences University (46.3\%; Dhindsa et al., 2010). This suggested that the fresh cases might have had encountered in the field at the time of surgery while at referral institutes most of the dystocia cases could be delayed. It is hypothesized that stress of transport along with stress of dystocia may further reduce the survival rate at referral institutes.

Table 3 shows the survival and conception rates of cesarean operated animals in relation to duration of dystocia. In both cattle and buffalo, the survival rate decreased with increase in duration of occurrence of dystocia (83.3 to 39.0 and 66.7 to $41.7 \%$, respectively). C-sections performed later than $36 \mathrm{~h}$ after onset of dystocia lead to low survivability in dam owing to endotoxaemic shock, haemorrhage, oedema of the uterus and dehydration (Sloss, 1974 and Saxena et al., 1989). 
Table.1 Questionnaire used for collection of data from the veterinarians

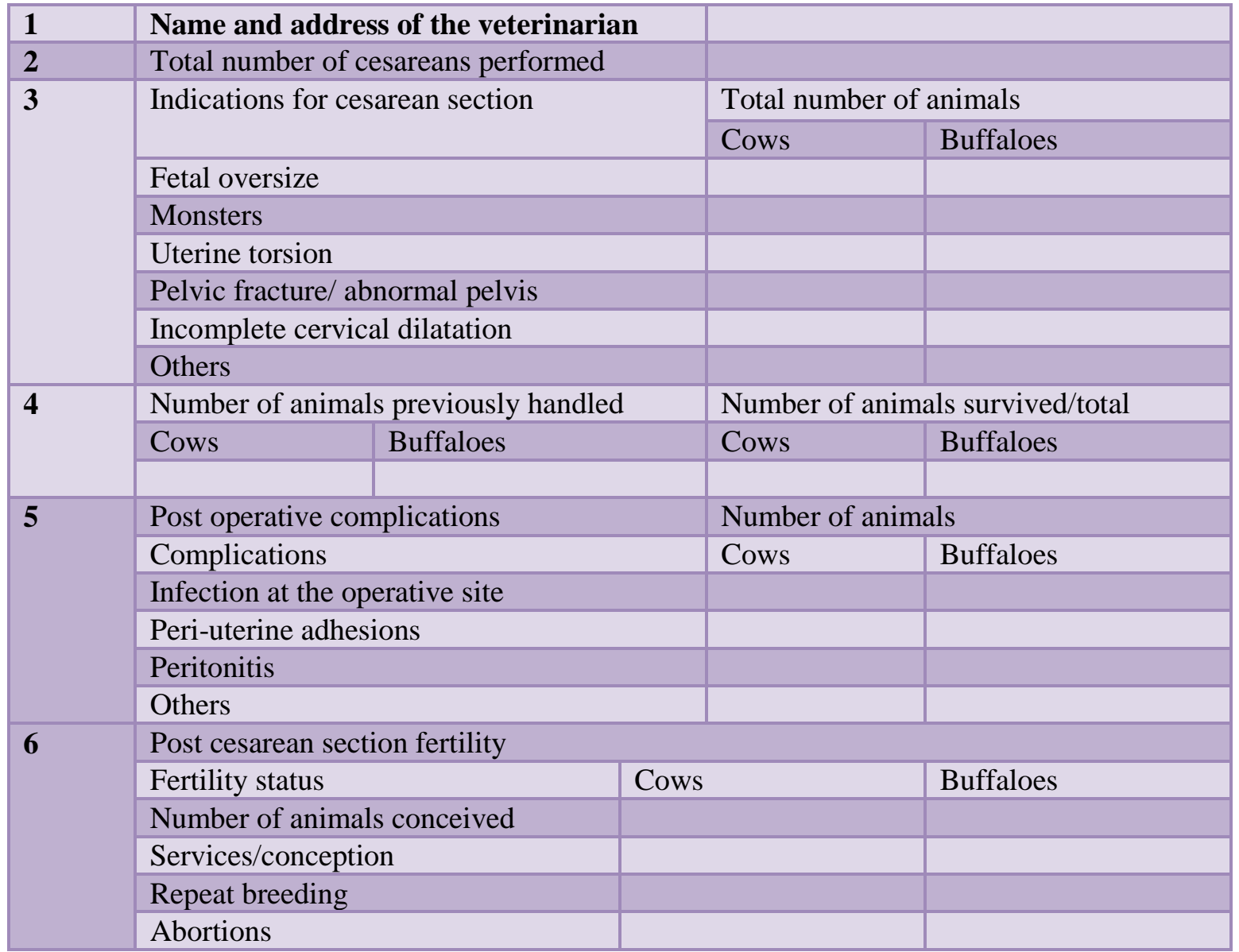

Table.2 Survival rate in cesarean operated animals with reference to various indications for the operation

\begin{tabular}{|c|c|c|c|}
\hline \multirow{2}{*}{$\begin{array}{c}\text { Indications for } \\
\text { caesarean }\end{array}$} & \multicolumn{3}{|c|}{$\begin{array}{c}\text { Number of survived animals /total } \\
(\%)\end{array}$} \\
\cline { 2 - 4 } & Cattle & Buffalo & Combined \\
\hline Fetal oversize & $13 / 20$ & $9 / 18$ & $21 / 38$ \\
& $(65.0)$ & $(50.0)$ & $(55.3)$ \\
\hline Monster & $2 / 3$ & $5 / 8$ & $7 / 11$ \\
& $(66.6)$ & $(62.5)$ & $(63.6)$ \\
\hline Uterine torsion & $1 / 2$ & $5 / 10$ & $6 / 12$ \\
\hline Incomplete cervical & $(50.0)$ & $(5.0)$ & $(50.0)$ \\
\hline dilatation & $19 / 25$ & $9 / 17$ & $(66.7)$ \\
\hline Pelvic fracture/ & $(76.0)$ & $(64.7)$ & $21 / 31$ \\
abnormal pelvis & $14 / 20$ & $7 / 11$ & $(67.7)$ \\
\hline Overall & $(70.0)$ & $(63.6)$ & $84 / 128$ \\
& $49 / 70$ & $35 / 58$ & $(65.6)$ \\
\hline
\end{tabular}


Table.3 Survival and fertility rates in cesarean operated animals in relation to duration of dystocia

\begin{tabular}{|c|c|c|c|c|c|c|}
\hline \multirow{2}{*}{$\begin{array}{l}\text { Duration of } \\
\text { dystocia }\end{array}$} & \multicolumn{2}{|c|}{ Cattle } & \multicolumn{2}{|c|}{ Buffalo } & \multicolumn{2}{|c|}{ Combined } \\
\hline & $\begin{array}{c}\text { Survived/ } \\
\text { Total } \\
(\%)\end{array}$ & $\begin{array}{c}\text { Conceived/ } \\
\text { Survived } \\
(\%)\end{array}$ & $\begin{array}{c}\text { Survived/ } \\
\text { Total } \\
(\%)\end{array}$ & $\begin{array}{c}\text { Conceived/ } \\
\text { Survived } \\
(\%)\end{array}$ & $\begin{array}{c}\text { Survived/ } \\
\text { Total } \\
(\%)\end{array}$ & $\begin{array}{c}\text { Conceived/ } \\
\text { Survived } \\
(\%)\end{array}$ \\
\hline $\begin{array}{c}A \\
(<12 \mathrm{~h})\end{array}$ & $\begin{array}{c}25 / 30 \\
(83.3)^{* *}\end{array}$ & $\begin{array}{l}6 / 25 \\
(24.0)\end{array}$ & $\begin{array}{l}20 / 30 \\
(66.7)\end{array}$ & $\begin{array}{c}2 / 20 \\
(10.0)\end{array}$ & $\begin{array}{c}45 / 60 \\
(75.0)\end{array}$ & $\begin{array}{l}8 / 45 \\
(17.8)\end{array}$ \\
\hline $\begin{array}{c}\text { B } \\
(12-36 ~ h)\end{array}$ & $\begin{array}{c}15 / 20 \\
(75.0)^{* * *}\end{array}$ & $\begin{array}{c}0 / 15 \\
(0)\end{array}$ & $\begin{array}{l}10 / 16 \\
(62.5)\end{array}$ & $\begin{array}{c}0 / 10 \\
(0)\end{array}$ & $\begin{array}{l}25 / 36 \\
(69.4)\end{array}$ & $\begin{array}{c}0 / 25 \\
(0)\end{array}$ \\
\hline $\begin{array}{c}C \\
(>36 h)\end{array}$ & $\begin{array}{c}9 / 20 \\
(39.0)\end{array}$ & $\begin{array}{l}0 / 9 \\
(0)\end{array}$ & $\begin{array}{c}5 / 12 \\
(41.7)\end{array}$ & $\begin{array}{l}0 / 5 \\
(0)\end{array}$ & $\begin{array}{l}14 / 32 \\
(43.8)\end{array}$ & $\begin{array}{c}0 / 14 \\
(0)\end{array}$ \\
\hline Overall & $\begin{array}{l}49 / 70 \\
(70.0)\end{array}$ & $\begin{array}{c}6 / 49 \\
(12.2)\end{array}$ & $\begin{array}{l}35 / 58 \\
(60.3)\end{array}$ & $\begin{array}{l}2 / 35 \\
(5.7)\end{array}$ & $\begin{array}{c}84 / 128 \\
(65.6)\end{array}$ & $\begin{array}{l}8 / 84 \\
(9.5)\end{array}$ \\
\hline
\end{tabular}

In the current analysis, about 18 per cent cesarean operated animals conceived when they were subjected to c-section within $12 \mathrm{~h}$ of occurrence of dystocia, however none of the animals conceived subsequently that previously had $\mathrm{c}$-section more than $12 \mathrm{~h}$ after the occurrence of dystocia. This might be due to higher tendency of formation of uterine adhesions in delayed cases, thus, hindering the involution of uterus. Previous studies have also indicated higher plasma fibrinogen concentrations, stress, tissue damage and post-cesarean uterine adhesion formation in prolonged cases of dystocia (Dhindsa et al., 2009 and Dhindsa et al., 2010). The present observations are also in concurrent with the findings of previous report that total dam survival rate for $73 \mathrm{c}$-sections performed by practitioners in the field was 67.1 per cent whereas for 102 operations performed at referral centers; dam survival was only 43.2 per cent (Singh and Dhaliwal, 1998). Similarly, Murthy et al., (1999) observed that 87 per cent of the cases survived when csection was done under institutional conditions and 96 per cent survived under field conditions and observed 100 per cent maternal survival rate when c-section was performed within $24 \mathrm{~h}$ of dystocia.

The current results suggested that the postcesarean survivability and future fertility may be improved if surgery is performed within 12 $\mathrm{h}$ of onset of occurrence of dystocia, and prompt and wise decision regarding c-section as treatment to relieve dystocia is taken without injudicious handling of the animal. The current findings offer some guidelines for the prognostic evaluation of dystocia affected bovine for c-section.

\section{References}

Dhindsa, S.S., Dhaliwal, G.S., Sood N.K., and Ghuman, S.P.S. 2009. Blood biochemical and uterine tissue alterations in relation to duration of dystocia in caesarean-operated bovines. Indian J. Anim. Sci. 79 (1): 30-33.

Dhindsa, S.S., Dhaliwal, G.S., and Ghuman, S.P.S. 2010. Factors influencing the dam survival rate in bovines subjected to caesarean section. Indian J. Anim. Rep. 31: 49-51. 
Murthy, K.K., Prasad, V., and Murthy, P.R.K. 1999. Clinical observations on uterine torsion in buffaloes. Indian Vet. J. 76: 643-645.

Prabhakar, S., Nanda, A.S., and Ghuman, S.P.S. 2002. Changes in plasma cortisol concentrations as an index of stress due to dystocia and obstetrical manoevering in buffaloes. Indian $\mathrm{J}$. Anim. Sc. 72: 309-311.

Purohit, G.N., Kumar, P, Solanki, K., Shekher, C., and Yadav, S.P. 2012. Perspectives of fetal dystocia in cattle and buffalo. Vet. Sci. Dev. 2: 231-242.

Saxena, O.P., Varshney, A.C., Jadon, N.S., Sharma, V.K., and Dabas, Y.P.S. 1989. Surgical management of dystocia in bovine: A clinical study. Indian Vet. J. 65: 562-66.
Singh, J. 1996. Studies on the uterine adhesions following caesarean operation in buffaloes. M.V.Sc. thesis submitted to Punjab Agricultural University, Ludhiana, India.

Singh, J., and Dhaliwal, G.S. 1998. A retrospective study on survivability and fertility following caesarean section in bovines. Indian J. Anim. Rep. 19: 2123.

Singh, J., Dhaliwal, G.S., and Jagir, S. 2002. Efficacy of different treatments in preventing uterine adhesions following caesarean section to relieve dystocia in buffaloes. Indian J. Anim. Sci. 72: 648651.

Sloss, V. 1974. A clinical study of dystocia in cattle-I Treatment. Aust. Vet. J. 50: 290-93.

\section{How to cite this article:}

Dhindsa, S.S., G.S. Dhaliwal, Harpreet Singh and Ghuman, S.P.S. 2019. A Retrospective Study on Consequences of Cesarean Section in Bovine Int.J.Curr.Microbiol.App.Sci. 8(01): 480-484. doi: https://doi.org/10.20546/ijcmas.2019.801.051 